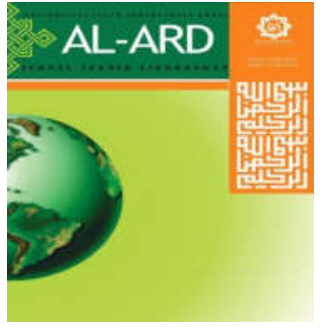

AL-ARD: JURNAL TEKNIK LINGKUNGAN Vol.4 No.1 - September 2018 (31-38)

AL-ARD

JURNAL TEKNIK LINGKUNGAN

www.al-ard.uinsby.ac.id

\title{
EVALUASI PENGELOLAAN SAMPAH PADA BANK SAMPAH DI DESA/KELURAHAN LARANGAN SIDOARJO
}

\author{
Dyah Ratri Nurmaningsih 1, Rita Ernawati 2 \\ 1 UIN Sunan Ampel Surabaya \\ dyahratrin@uinsby.ac.id \\ 2 UIN Sunan Ampel Surabaya \\ rita_ernawati@uinsby.ac.id
}

\begin{abstract}
Garbage is still seen by some people as waste that is not useful, not as a resource that can be utilized. The approach to reduce at source and recycle resources through the implementation of $3 \mathrm{R}$ is a more comprehensive waste management policy. Sidoarjo Regency as one of the buffer zones of Surabaya City on a daily basis produces a large volume of waste. Based on data from the Department of Sanitation and Landscaping of Sidoarjo Regency, waste management in the region has not been implemented comprehensively. Although around 100 units of Garbage Banks have been formed on a community scale, the operational activities of each unit have not been optimal. This study used descriptive qualitative method. Data was obtained by direct interviews with the Village / Village residents of the Prohibition and questionnaire, which were then analyzed. The amount of waste volume managed every month on average (Kg) shows a good amount. Waste waste is also used to increase the income of the waste bank customers in particular. Problems that occur both internal problems of institutions, technical problems, and problems outside the institution, internal problems of the institution that occur quite a lot is due to lack of awareness of the community to participate in waste management, while technical issues and problems outside the institution are not so significant. The existence of government support is needed in the sustainability of the waste bank in the Larangan District of Sidoarjo Regency, while the government support that has been implemented includes the provision of composter, supporting equipment, savings books and socialization to the community.

Keywords: Garbage, waste management, waste bank
\end{abstract}

\begin{abstract}
Abstrak
Sampah masih dipandang oleh sebagian masyarakat sebagai barang sisa yang tidak berguna, bukan sebagai sumber daya yang dapat dimanfaatkan. Pendekatan reduce at source dan resource recycle melalui penerapan 3R merupakan kebijakan pengelolaan sampah yang lebih komprehensif. Kabupaten Sidoarjo sebagai salah satu wilayah penyangga Kota Surabaya dalam setiap harinya menghasilkan volume sampah yang cukup besar. Berdasarkan data Dinas Kebersihan dan Pertamanan Kabupaten Sidoarjo pengelolaan sampah di wilayah tersebut belum dilaksanakan secara komprehensif. Meskipun telah terbentuk sekitar 100 unit Bank Sampah dalam skala komunitas, operasional kegiatan masing-masing unit belum optimal. Penelitian ini menggunakan metode deskriptif kualitatif. Data diperoleh dengan wawancara langsung dengan penduduk Desa/Kelurahan Larangan dan kuisioner, yang kemudian dianalisa. Besaran volume sampah yang dikelola tiap bulan rata-rata (Kg) menunjukkan jumlah yang baik. Limbah sampah juga dimanfaatkan untuk meningkatkan pendapatan para nasabah bank sampah khususnya. Permasalahan yang terjadi baik permasalahan internal lembaga, permasalahan teknis, dan permasalahan di luar lembaga, permasalahan internal lembaga yang terjadi cukup banyak hal ini dikarenakan kurangnya kesadaran masyarakat berpartisipasi dalam pengelolaan sampah, sedangkan permasalahan teknis dan permasalahan diluar lembaga tidak begitu signifikan. Adanya dukungan pemerintah sangat diperlukan dalam keberlanjutan bank sampah di Kelurahan Larangan Kabupaten Sidoarjo, adapun dukungan pemerintah yang telah dilaksanakan meliputi pemberian komposter, peralatan penunjang, buku tabungan serta sosialisasi pada masyarakat.
\end{abstract}

Kata Kunci: Sampah, pengelolaan sampah, bank sampah 


\section{PENDAHULUAN}

Data Kementerian Lingkungan Hidup pada tahun 2012 menunjukkan bahwa rata-rata penduduk Indonesia menghasilkan 2 (dua) kilogram sampah per orang per hari. Artinya sebanyak 490 ribu ton sampah dihasilkan setiap hari. Sampah tidak hanya mengakibatkan bau tidak sedap dan mengganggu pandangan, namun juga dapat menimbulkan permasalahan kesehatan secara masif. Selain itu gas metan yang dihasilkan dari proses dekomposisi secara anaerob berkontribusi pada pemanasan global melalui peningkatan suhu $1,3^{\circ} \mathrm{C}$ per tahun jika berada pada atmosfer selama kurun waktu 7-10 tahun.

Sampah masih dipandang oleh sebagian besar masyarakat sebagai barang sisa yang tidak berguna, bukan sebagai sumber daya yang dapat dimanfaatkan. Kebijakan pengelolaan sampah yang selama lebih dari tiga dekade hanya bertumpu pada pendekatan kumpul-angkut-buang (end of pipe) dengan mengandalkan keberadaan TPA harus berubah. Paradigma lama mengakibatkan timbunan sampah dengan volume yang besar di lokasi tempat pemrosesan akhir sampah berpotensi melepas gas metan (CH4) yang dapat meningkatkan emisi gas rumah kaca dan memberikan kontribusi terhadap pemanasan global. Pendekatan reduce at source dan resource recycle melalui penerapan 3R merupakan kebijakan pengelolaan sampah yang lebih komprehensif. Transformasi pengelolaan sampah dari paradigma yang bertumpu pada pendekatan akhir harus dilakukan dengan paradigma baru pengelolaan sampah. Paradigma baru memandang sampah sebagai sumber daya yang mempunyai nilai ekonomi dan dapat dimanfaatkan (energi alternatif, kompos, ataupun untuk bahan baku industri). Pengelolaan sampah perlu dilakukan dengan pendekatan komprehensif dari hulu, sejak sebelum dihasilkan suatu produk yang berpotensi menjadi sampah, sampai ke hilir, yaitu pada fase produk sudah digunakan sehingga menjadi sampah, yang kemudian dikembalikan ke media lingkungan secara aman.

Menurut UU No 18 Tahun 2008, pengelolaan sampah dengan paradigma baru dilakukan dengan kegiatan pengurangan dan penanganan sampah. Pengurangan sampah meliputi kegiatan pembatasan, penggunaan kembali, dan pendauran ulang, sedangkan kegiatan penanganan sampah meliputi pemilahan, pengumpulan, pengangkutan, pengolahan, dan pemrosesan akhir. Pelibatan organisasi persampahan, dan kelompok masyarakat yang bergerak di bidang persampahan harus dilakukan dalam rangka menyelenggarakan pengelolaan sampah secara terpadu dan komprehensif.

Untuk mengatur pelaksanaan pengelolaan sampah dengan paradigma baru pemerintah merumuskan Peraturan Pemerintah No. 81 Tahun 2012 tentang Pengelolaan Sampah Rumah Tangga dan Sampah Sejenis Sampah Rumah Tangga. Kebijakan tersebut mensyaratkan praktek mengolah dan memanfaatkan sampah sebagai langkah nyata dalam mengelola sampah, meninggalkan cara lama yang hanya membuang sampah dengan mendidik dan membiasakan masyarakat memilah, memilih, dan menghargai sampah sekaligus mengembangkan ekonomi kerakyatan melalui pengembangan Bank Sampah.

Di tengah rendahnya kesadaran masyarakat untuk malaksanakan program 3R, bank sampah merupakan salah satu solusi. Konsep pengembangan Bank bersifat social engineering yang mengajarkan masyarakat untuk memilah sampah serta menumbuhkan kesadaran masyarakat dalam pengolahan sampah secara bijak dan pada gilirannya akan mengurangi sampah yang diangkut ke TPA. Pengembangan bank sampah harus menjadi momentum awal membina kesadaran kolektif masyarakat untuk memulai memilah, mendaur-ulang, dan memanfaatkan sampah, karena sampah mempunyai nilai jual yang cukup baik, sehingga pengelolaan sampah yang berwawasan lingkungan menjadi budaya baru Indonesia (Yayasan Unilever Indonesia, 2013).

Bank Sampah mengemban peran penting dengan terbitnya Peraturan Pemerintah Nomor 81 tahun 2012 tentang Pengelolaan Sampah Rumah Tangga dan Sampah Sejenis Sampah Rumah Tangga yang mewajibkan produsen melakukan kegiatan 3R dengan cara menghasilkan produk dengan menggunakan kemasan yang mudah diurai oleh proses alam dan yang menimbulkan sampah sesedikit mungkin, menggunakan bahan baku produksi yang dapat didaur ulang dan diguna ulang dan/atau menarik kembali sampah dari produk dan kemasan produk untuk didaur 
ulang dan diguna ulang. Bank Sampah dapat berperan sebagai dropping point bagi produsen untuk produk dan kemasan produk yang masa pakainya telah usai. Berdasarkan statistik perkembangan pembangunan Bank Sampah di Indonesia pada bulan Februari 2012 jumlah Bank Sampah sebanyak 471 unit (aktif) dengan jumlah nasabah sebanyak 47.125 orang dengan jumlah sampah yang terkelola adalah $755.600 \mathrm{~kg} /$ bulan dengan nilai perputaran uang sebesar Rp. 1.648.320.000 perbulan. Angka statistik ini meningkat berdasarkan data bulan Mei 2012 dimana jumlah Bank Sampah menjadi 886 unit (aktif), dengan jumlah nasabah sebanyak 84.623 orang dan jumlah sampah yang terkelola sebesar $2.001 .788 \mathrm{~kg} / \mathrm{bulan}$ serta menghasilkan uang sebesar Rp. 3.182.281.000 perbulan.
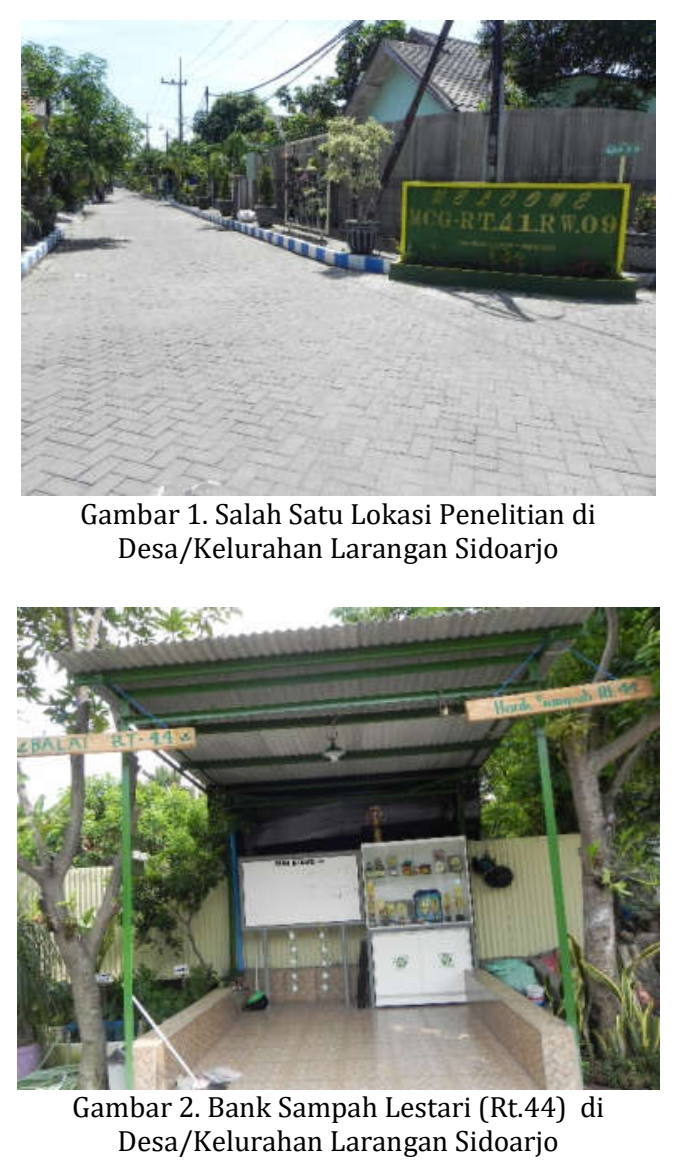

Kabupaten Sidoarjo sebagai salah satu wilayah penyangga Kota Surabaya dalam setiap harinya menghasilkan volume sampah yang cukup besar. Berdasarkan data Dinas Kebersihan dan Pertamanan Kabupaten Sidoarjo pengelolaan sampah di wilayah tersebut belum dilaksanakan secara komprehensif. Meskipun telah terbentuk sekitar 100 unit Bank Sampah dalam skala komunitas, operasional kegiatan masingmasing unit belum optimal. Mengingat pentingnya peran Bank Sampah dalam pengelolaan sampah secara komprehensif perlu dilakukan evaluasi eksistensi dan kinerja bank sampah, selain itu juga perlu dirumuskan rencana tindak (action plan) pengembangan bank sampah di Kabupaten Sidoarjo. Penelitian ini dilakukan dalam rangka mengetahui kebutuhan tersebut agar pengelolaan sampah di Kabupaten Sidoarjo dapat berjalan secara optimal.

\section{METODE PENELITIAN}

Metode yang digunakan adalah deskriptif kualitatif. Data primer penelitian ini diperoleh dengan melakukan wawancara secara langsung dengan penduduk Desa/Kelurahan Larangan dan kuisioner. Kemudian dari data wawancara dan kuisioner dianalisis dengan pembahansaanya. Adapun data skunder seperti profil Desa, diperoleh dari Dinas Kesehatan Kabupaten Sidoarjo.

\section{HASIL DAN PEMBAHASAN \\ Gambaran Umum Kondisi Wilayah Kelurahan Larangan}

Kelurahan Larangan terletak di Kecamatan Candi Kabupaten Sidoarjo Jawa Timur dengan luas wilayah 77,617 Ha. Secara administratif, Kelurahan Larangan dengan batas wilayah sebagai berikut:

Sebelah Utara : Kelurahan Sidokare, Kelurahan Kelep dan Kelurahan Sekardangan

Sebelah Timur : Ds. Blingo dan Kelurahan Sekardangan

Sebelah Selatan : Ds. Blingo dan Ds. Tenggulunan

Sebelah Barat : Ds. Sumukali dan Kelurahan Sidokare

Berdasarkan (Profil Desa/Kelurahan, 2015) struktur mata pencaharian terdapat 8 jenis mata pencaharian baik formal maupun non formal. Mata pencaharian pada sektor formal (karyawan swasta, PNS, dll) sangat mandominasi dibandingkan mata pencaharian pada sektor informal (petani, pedagang, dll). Keberagaman tersebut tidak menjadikan terjadinya kehidupan sosial yang negative. Pesatnya perkembangan ekonomi di kelurahan Larangan menyebabkan tingkan konsumsi masyarakat juga semakin banyak sehingga sampah yang dihasilkan juga meningkat. Walaupun demikian data 
permasalahan sosal dan permasalahan lingkungan di Kelurahan Larangan menunjukkan angka yang relatif kecil. Dari aspek kondisi rumah, semua rumah berkondisi baik dengan bangunan permanen yang terdiri dari material dinding tembok, lantai keramik dan atap genteng. Kondisi tersebut menunjukkan bahwa tingkat perekonomian masyarakat Kelurahan Larangan sangat baik.

\section{Identifikasi Hasil Survei}

Dari hasil identifikasi survey berdasarkan kusioner diperoleh data jumlah nasabah aktif, volume sampah yang dikelola tiap bulan ratarata dan omzet tiap bulan. Tabel 1 Identifikasi Hasil Survey dapat dilihat di bawah ini.

Tabel 1. Identifikasi Hasil Survey Bank Sampah di Desa/Kelurahan Larangan Sidoarjo.

\begin{tabular}{|c|c|c|c|c|}
\hline No & $\begin{array}{c}\text { Nama Bank } \\
\text { Sampah }\end{array}$ & $\begin{array}{c}\text { Jumlah } \\
\text { nasabah } \\
\text { aktif }\end{array}$ & $\begin{array}{c}\text { Volume } \\
\text { Sampah } \\
\text { Rata2 } \\
\text { per } \\
\text { Bulan } \\
\text { (Kg) } \\
\end{array}$ & $\begin{array}{l}\text { Omzet per } \\
\text { Bulan (Rp) }\end{array}$ \\
\hline 1 & $\begin{array}{l}\text { Bank Sampah } \\
\text { RT } 33\end{array}$ & 20 & $50-70$ & $\begin{array}{c}100.000,-\mathrm{s} / \mathrm{d} \\
150.000,-\end{array}$ \\
\hline 2 & Bolodewo & 35 & 200 & $\begin{array}{c}600.000,-\mathrm{s} / \mathrm{d} \\
700.000,-\end{array}$ \\
\hline 3 & RT. 32 RW.08 & 36 & 300 & $350.000,-$ \\
\hline 4 & $\begin{array}{l}\text { Saling Asih } \\
\text { (Sadar } \\
\text { Lingkungan } \\
\text { Anggrek } \\
\text { Bersih) } \\
\end{array}$ & 44 & 549 & 1.050.000,- \\
\hline 5 & RT.47 RW.09 & 60 & 300 & 500.000 ,- \\
\hline 6 & Lestari & 29 & 500 & $700.000,-$ \\
\hline 7 & Tangguh & 24 & 30 & $\begin{array}{c}100.000,-\mathrm{s} / \mathrm{d} \\
150.000,-\end{array}$ \\
\hline 8 & RT.40 RW.09 & 18 & 30 & 150.000,- \\
\hline 9 & Empat Lima & 20 & 50 & 100.000,- \\
\hline 10 & Berseri & 34 & 80 & 172.000,- \\
\hline 11 & Rambadia & 18 & $50-100$ & $\begin{array}{c}100.000,-\mathrm{s} / \mathrm{d} \\
150.000,-\end{array}$ \\
\hline 12 & Telu Songgo & 43 & 380 & $750.000,-$ \\
\hline 13 & RT.11 RW.03 & 60 & 30 & $\begin{array}{c}60.000,-\mathrm{s} / \mathrm{d} \\
100.000,-\end{array}$ \\
\hline 14 & RT.19 RW.05 & 12 & 50 & 60.000,- \\
\hline 15 & RT.41 RW.09 & 11 & 12 & 100.000,- \\
\hline
\end{tabular}

Tabel diatas menunjukkan jumlah nasabah bank sampah yang aktif di desa/kelurahan Larangan Kabupaten Sidoarjo. Jumlah nasabah yang aktif tersebut menggambarkan bahwa kesadaran masyarakat dalam berpartisipasi pada pengembangan bank sampah khususnya di kelurahan Larangan Kabupaten Sidoarjo semakin membaik. Jumlah nasabah aktif paling tinggi berasal dari bank sampah RT.47 RW.09 dan RT.11 RW.03 dengan jumlah @60 orang. Sedangkan jumlah terendah yaitu 11 orang, berasal dari bank sampah RT.41 RW.09.

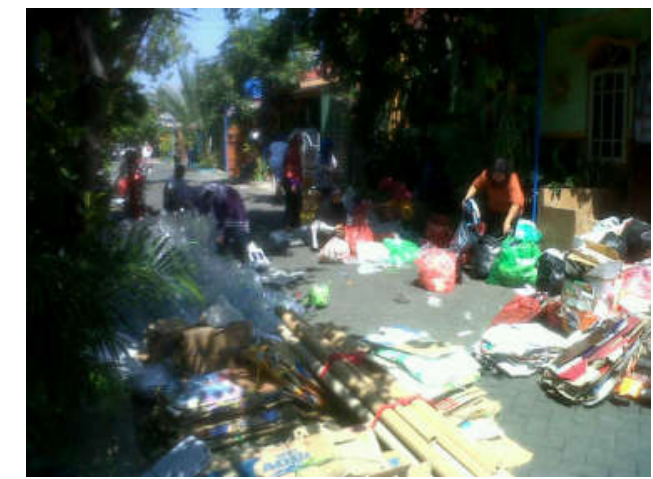

Gambar 3. Kegiatan Memilah Sampah pada Salah Satu Bank Sampah di Desa/Kelurahan Larangan Sidoarjo

Bank sampah adalah tempat menabung sampah, dimana sampah yang ditabung pada bank sampah adalah sampah yang mempunyai nilai ekonomis. Sampah yang memiliki nilai ekonomis atau nilai jual adalah sampah yang dapat dimanfaatkan kembali dan dapat didaur ulang menjadi suatu produk baru. Jika dalam bank-bank umumnya yang disetorkan berupa uang, sedangkan dalam bank sampah yang disetorkan berupa sampah yang telah terpilah menurut jenis sampah dan mempunyai nilai ekonomis. Pengelolaan sampah yang dilaksanakan pada bank sampah di kelurahan Larangan Kabupaten Sidoarjo sudah baik. Hal tersebut terlihat dari besaran volume sampah yang di kelola tiap bulan rata-rata $(\mathrm{Kg})$ pada tabel 1. Besar volume sampah yang dikelola tiap bulan dengan besaran rata-rata lebih $\geq$ $100 \mathrm{~kg}$ berasal dari bank sampah Bolodewo, RT. 32 RW.08, Saling Asih (Sadar Lingkungan Anggrek Bersih), RT.47 RW.09, Lestari, Rambadia dan Telu Songgo. Sedangkan volume terendah berasal dari bank sampah RT.41 RW.09 yaitu sebesar $12 \mathrm{~kg}$ rata-rata per bulan.

Salah satu manfaat bagi masyarakat terkait berdirinya bank sampah adalah untuk peningkatan pendapatan bagi nasabah bank sampah khususnya di Kelurahan Larangan Kabupaten Sidoarjo. Jika dilihat dari tabel omzet per bulan , nilai omzet terbesar berasal dari bank sampah Saling Asih (Sadar Lingkungan Anggrek Bersih) Kelurahan Larangan sebesar Rp 1.050.000,00. 


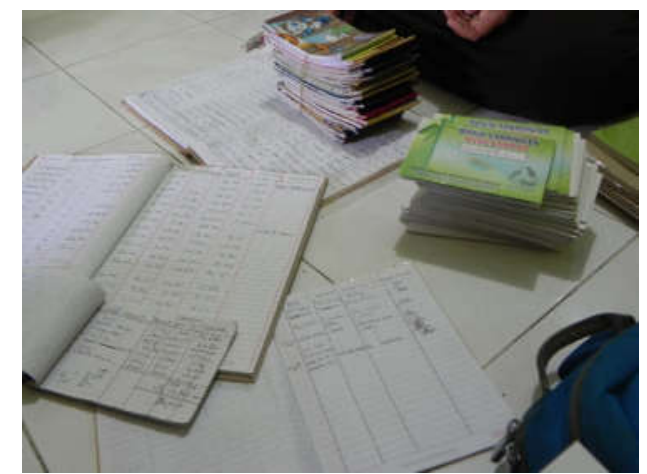

Gambar 4. Buku Tabungan Nasabah Bank Sampah di Desa/Kelurahan Larangan Sidoarjo

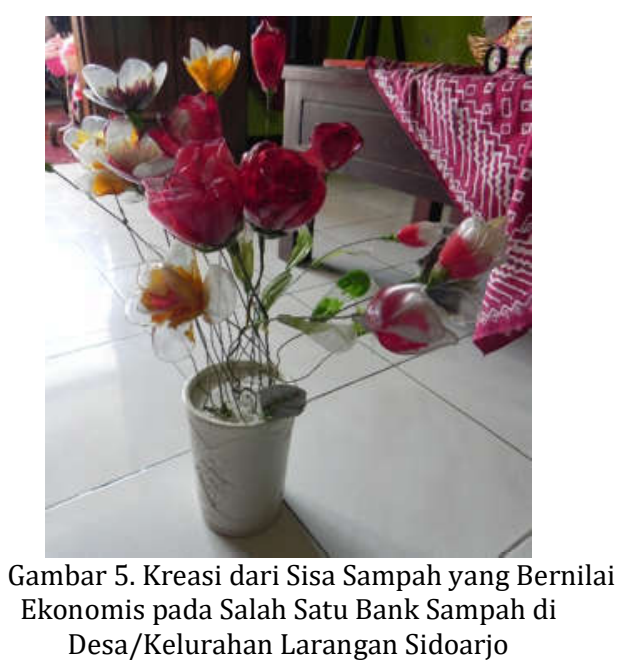

Analisis Potensi Dan Masalah Pengelolaan Bank Sampah

Analisis terhadap permasalahan pengelolaan bank sampah dilakukan terhadap permasalahan internal lembaga, permasalahan teknis, permasalahan di luar lembaga dan dukungan pemerintah. Berikut ini penjabaran hasil analisis terhadap permasalahan pengelolaan bank sampah di Kabupaten Sidoarjo.

\section{Permasalahan Internal Lembaga}

Berkaitan dengan permasalahan internal lembaga, bank sampah secara umum mengalami permasalahan terkait kurangnya kesadaran masyarakat, SDM pengelola, kurangnya sarana dan terkait permasalahan teknis. Tabel 2 di bawah ini menunjukkan bahwa kurangnya kesadaran masyarakat akan pentingnya pengelolaan sampah sangat dominan dan mendesak untuk ditangani karena hampir disetiap bank sampah mengalami permasalahan tersebut. Adapun beberapa bank sampah yang mengalami permasalahan terkait kurangnya SDM yang mau menjadi pengelola dan permasalahan teknis.

Tabel 2. Permasalahan Internal Lembaga pada Bank

Sampah di Desa/Kelurahan Larangan Sidoarjo.

\begin{tabular}{|c|c|c|}
\hline No & $\begin{array}{l}\text { Nama Bank } \\
\text { Sampah }\end{array}$ & $\begin{array}{c}\text { Permasalahan Internal } \\
\text { Lembaga }\end{array}$ \\
\hline 1 & $\begin{array}{ll}\text { Bank } & \\
\text { Sampah RT } \\
33\end{array}$ & $\begin{array}{lcc}\text { Kurangnya } & \text { kesadaran } & \text { dari } \\
\text { masyarakat dan minat } & \text { dari } \\
\text { masyarakat masih minim. } & \\
\end{array}$ \\
\hline 2 & Bolodewo & $\begin{array}{l}\text { Masih banyak warga yang enggan } \\
\text { untuk memilah sampah dan tidak } \\
\text { semua warga memiliki lahan } \\
\text { untuk menyimpan sampah }\end{array}$ \\
\hline 3 & $\begin{array}{l}\text { RT. } \\
\text { RW.08 }\end{array}$ & $\begin{array}{l}\text { Warga yang enggan untuk } \\
\text { memilah sampah }\end{array}$ \\
\hline 4 & $\begin{array}{l}\text { Saling Asih } \\
\text { (Sadar } \\
\text { Lingkungan } \\
\text { Anggrek } \\
\text { Bersih) } \\
\end{array}$ & $\begin{array}{l}\text { Belum ada bangunan serbaguna } \\
\text { untuk berbagai kegiatan yang ada } \\
\text { pada progran-program di Bank } \\
\text { Sampah }\end{array}$ \\
\hline 5 & RT.47 RW.09 & $\begin{array}{l}\text { Kesadaran masyarakat yang } \\
\text { masih kurang mengenai manfaat } \\
\text { bank sampah, san kesediaan } \\
\text { untuk memilah. }\end{array}$ \\
\hline 6 & Lestari & $\begin{array}{l}\text { Keluhan masyarakat karena } \\
\text { sampah yang menumpuk terlalu } \\
\text { lama dirumah }\end{array}$ \\
\hline 7 & Tangguh & $\begin{array}{l}\text { Tidak semua mau memilah } \\
\text { sampah dan sebagian langsung } \\
\text { dibuang tetapi tidsk disimpan }\end{array}$ \\
\hline 8 & RT.40 RW.09 & $\begin{array}{l}\text { Kurangnya kesadaran dari } \\
\text { masyarakat untuk memilah dan } \\
\text { mengumpulkan sampah }\end{array}$ \\
\hline 9 & Empat Lima & $\begin{array}{l}\text { Kurangnya kesadaran dari } \\
\text { masyarakat untuk memilah dan } \\
\text { mengumpulkan sampah, tidak } \\
\text { semua warga mengetahui jenis- } \\
\text { jenis sampah }\end{array}$ \\
\hline 10 & Berseri & $\begin{array}{l}\text { Kurangnya } \\
\text { masyarakat akan sampah dan } \\
\text { terhadap lingkungan }\end{array}$ \\
\hline 11 & Rambadia & $\begin{array}{l}\text { Kurangnya } \\
\text { masyarakat akan sampah dan } \\
\text { terhadap lingkungan }\end{array}$ \\
\hline 12 & Telu Songgo & $\begin{array}{l}\text { Kurangnya kesadaran dari tiap- } \\
\text { tiap warga, dan pola pemikiran } \\
\text { yang berbeda }\end{array}$ \\
\hline 13 & RT.11 RW.03 & $\begin{array}{l}\text { Ada beberapa waga yang } \\
\text { mmebawa sampah double dari } \\
\text { biasanya sehingga petugas } \\
\text { menjadi berat }\end{array}$ \\
\hline 14 & RT.19 RW.05 & $\begin{array}{l}\text { Kurangnya kesadaran dari tiap- } \\
\text { tiap warga }\end{array}$ \\
\hline 15 & RT.41 RW.09 & $\begin{array}{l}\text { Kurangnya kesadaran dari tiap- } \\
\text { tiap warga }\end{array}$ \\
\hline
\end{tabular}

\section{Permasalahan Teknis}

Operasional bank sampah di Kabupaten Sidoarjo dilakukan dengan mekanisme bottom up. Pengelolaan sampah dilakuakan dalam waktu yang telah ditentukan, nasabah mengumpulkan sampah yang sudah dipilah sejak dari rumah. Pengurus bank sampah 
melakukan pencatatan dan pengelompokan sampah untuk selanjutnya dijual oleh pengepul. Tempat yang digunakan untuk pengelolaan sampah sebagian besar menggunakan milik warga atau fasilitas umum diwilayah tersebut. Kondisi tersebut berimplikasi pada analisis permasalahan teknis dalam pengelolaan bank sampah, kemampuan mengelola keterbatasan sarana menjadikan sebagian besar bank sampah tidak merasa adanya permasalahan teknis. Dari tabel 3 di bawah ini memperlihatkan ada beberapa bank sampah yang mengalami permasalahan teknis yaitu permasalahan kurangnya tenaga SDM yang bertugas untuk memilah sampah ataupun mendaurulang sampah dan belum adanya lahan/tempat yang digunakan untuk menampung sampah.

Tabel 3. Permasalahan Teknis pada Bank Sampah di Desa/Kelurahan Larangan Sidoarjo.

\begin{tabular}{|c|c|c|}
\hline No & $\begin{array}{l}\text { Nama Bank } \\
\text { Sampah }\end{array}$ & Permasalahan Teknis \\
\hline 1 & $\begin{array}{l}\text { Bank Sampah RT } \\
33\end{array}$ & $\begin{array}{l}\text { Tidak memiliki tempat menetap } \\
\text { jadi penumpukan sampah pada } \\
\text { salah satu rumah warga }\end{array}$ \\
\hline 2 & Bolodewo & Tidak ada \\
\hline 3 & RT. 32 RW.08 & Tidak ada \\
\hline 4 & $\begin{array}{l}\text { Saling Asih (Sadar } \\
\text { Lingkungan } \\
\text { Anggrek Bersih) }\end{array}$ & Tidak ada \\
\hline 5 & RT.47 RW.09 & Tidak ada \\
\hline 6 & Lestari & Tidak ada \\
\hline 7 & Tangguh & Tidak ada \\
\hline 8 & RT.40 RW.09 & $\begin{array}{l}\text { Belum ada tenaga kerja untuk } \\
\text { mendaur ulang dan belum ada } \\
\text { pelatihan atau pengetahuan } \\
\text { mengenai daur ulang. }\end{array}$ \\
\hline 9 & Empat Lima & Tidak ada \\
\hline 10 & Berseri & $\begin{array}{l}\text { Tidak mempunyai tenaga kerja } \\
\text { untuk memilah dengan detail } \\
\text { sehingg yang memilah pengepul } \\
\text { sendiri }\end{array}$ \\
\hline 11 & Rambadia & $\begin{array}{l}\text { Tidak ada tenaga kerja untuk } \\
\text { memilah sampah }\end{array}$ \\
\hline 12 & Telu Songgo & Tidak ada \\
\hline 13 & RT.11 RW.03 & Tidak ada \\
\hline 14 & RT.19 RW.05 & Tidak ada \\
\hline 15 & RT.41 RW.09 & Tidak ada \\
\hline
\end{tabular}

Meskipun secara teknis operasional bank sampah di Kabupaten Sidoarjo tidak mengalami masalah yang signifikan, namun permasalahan internal lembaga terkait kesadaran masyarakat merupakan masalah besar yang berpengaruh pada keberlanjutan bank sampah. Untuk itu solusi non fisik dalam meningkatan kesadaran dan kapasitas SDM pengelola sangat penting untuk segera dialokasikan.

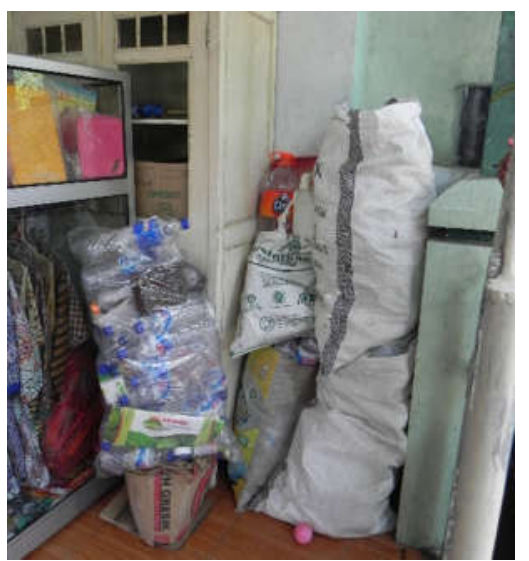

Gambar 6. Salah Satu Tempat Penyimpanan Sampah pada Rumah Penduduk di Desa/Kelurahan Larangan Sidoarjo

\section{Permasalahan di Luar Lembaga}

Selain analisis permasalahan internal lembaga dan permasalahan teknis, dilakukan juga analisis terhadap permasalahan di luar lembaga dan bentuk dukungan pemerintah terhadap bank sampah di Kabupaten Sidoarjo. Hal ini dilakukan agar permasalahan yang disebabkan dari dalam dan luar lembaga terkait dengan bank sampah di Kabupaten Sidoarjo dapat diidentifikasi dengan benar. Berikut penjabaran hasil analisis terhadap permasalahan di luar lembaga dan bentuk dukungan pemerintah terhadap bank sampah di Kabupaten Sidoarjo.

Tabel 4. Permasalahan di Luar Lembaga pada Bank Sampah di Desa/Kelurahan Larangan Sidoarjo.

\begin{tabular}{cclc}
\hline No & Nama Bank Sampah & \multicolumn{1}{c}{$\begin{array}{c}\text { Permasalahan di Luar } \\
\text { Lembaga }\end{array}$} \\
\hline 1 & Bank Sampah RT 33 & Tidak ada & \\
\hline 2 & Bolodewo & $\begin{array}{l}\text { Tidak ada, sudah } \\
\text { membantu } \\
\text { penyumbangan peralatan } \\
\text { dalam }\end{array}$ \\
\hline 3 & RT. 32 RW.08 & $\begin{array}{l}\text { Tidak ada, sudah cukup } \\
\text { membantu } \\
\text { penyumbangan peralatan }\end{array}$ \\
\hline 4 & Lingkungan Anggrek & $\begin{array}{l}\text { Tidak ada, sudah cukup } \\
\text { penyumbantu } \\
\text { dan motivasi }\end{array}$ \\
\hline 5 & RT.47 RW.09 & $\begin{array}{l}\text { Diberi alat timbang namun } \\
\text { belum bisa dipakai }\end{array}$ \\
\hline 6 & Lestari & $\begin{array}{l}\text { Alat timbang dari unilever } \\
\text { yang tidak valid, dan berbeda } \\
\text { dengan pengepul }\end{array}$ \\
\hline
\end{tabular}




\begin{tabular}{cll}
\hline No & Nama Bank Sampah & \multicolumn{1}{c}{$\begin{array}{c}\text { Permasalahan di Luar } \\
\text { Lembaga }\end{array}$} \\
\hline 7 & Tangguh & $\begin{array}{l}\text { Tidak ada yang memberi } \\
\text { gerobak }\end{array}$ \\
\hline & & $\begin{array}{l}\text { Timbangan yang diberi } \\
\text { unilever masih minim. Tidak } \\
\text { dapat digunakan untuk } \\
\text { sampah yang berukuran } \\
\text { besar. }\end{array}$ \\
\hline 9 & RT.40 RW.09 & Tidak ada \\
\hline 10 & Berseri & Tidak ada \\
\hline 11 & Rambadia & $\begin{array}{l}\text { Dari unilever menghimbau } \\
\text { akan memberi buku } \\
\text { tabungan dan buku adm } \\
\text { namun tidak kunjung diberi. }\end{array}$ \\
\hline 12 & Telu Songgo & Tidak ada \\
\hline 13 & RT.11 RW.03 & $\begin{array}{l}\text { Belum ada komposter dari } \\
\text { BLH }\end{array}$ \\
\hline 14 & RT.19 RW.05 & Tidak ada \\
\hline 15 & RT.41 RW.09 & Tidak ada \\
\hline (Sumber: Hasil Penelitian) & & \\
\hline
\end{tabular}

Pada tabel 4 di atas menjelaskan bahwa sebagian besar bank sampah tidak memiliki permasalahan di luar lembaga yang signifikan. Beberapa masalah seperti peralatan timbangan yang digunakan masih belum dikalibrasi sehingga hasinya tidak falid, belum adanya komposter serta belum adanya buku tabungan yang digunakan sebagai laporan data-data masyarakat yang telah menyetorkan sampah pada bank sampah, hanya terjadi di beberapa bank sampah saja.

\section{Bentuk Dukungan Pemerintah}

Kabupaten Sidoarjo sebagai salah satu wilayah penyangga Kota Surabaya dalam setiap harinya menghasilkan volume sampah yang cukup besar, telah terbentuk secara sekitar 100 unit Bank Sampah dalam skala komunitas. Mengingat pentingnya peran Bank Sampah dalam pengelolaan sampah diharapkan pengembangan bank sampah dapat dilaksanakan dengan baik sehingga pengelolaan sampah di Kabupaten Sidoarjo dapat berjalan optimal. Oleh karena itu Pemerintah Kabupaten Sidoarjo sangat mendukung adanya pendirian bank sampah, hal ini dapat dilihat dari upaya pemerintah Kabupaten Sidoarjo dalam melibatkan bebepara elemen pemerintahan yang turut serta dalam pengelolaan dan pengembangan bank sampah, seperti Dinas Kebersihan dan Pertamanan Kabupaten Sidoarjo, Badan Lingkungan Hidup Kabupaten Sidoarjo dan Keluran yang terkait. Dukungan tersebut berupa pemberian alat, seperti komposter dan gerobak serta terkait dengan kesadaran masayarakat yaitu berupa motivasi dan sosialisasi mengenai bank sampah. Berikut adalah bentuk dukungan pemerintah pada bank sampah di Desa/Kelurahan Larangan Sidoarjo yang dijabarkan pada tabel 5 di bawah ini.

Tabel 5. Dukungan Pemerintah pada Bank Sampah di Desa/Kelurahan Larangan Sidoarjo.

\begin{tabular}{|c|c|c|}
\hline No & $\begin{array}{l}\text { Nama Bank } \\
\text { Sampah }\end{array}$ & $\begin{array}{c}\text { Bentuk Dukungan } \\
\text { Pemerintah }\end{array}$ \\
\hline 1 & Bank Sampah RT 33 & BLH berupa komposter \\
\hline 2 & Bolodewo & Tidak ada \\
\hline 3 & RT. 32 RW.08 & $\begin{array}{l}\text { DKP dan BLH berupa } \\
\text { gerobak sampah }\end{array}$ \\
\hline 4 & $\begin{array}{l}\text { Saling Asih (Sadar } \\
\text { Lingkungan } \\
\text { Anggrek Bersih) }\end{array}$ & $\begin{array}{l}\text { BLH berupa buku } \\
\text { tabungan }\end{array}$ \\
\hline 5 & RT.47 RW.09 & $\begin{array}{l}\text { DKP dan BLH berupa } \\
\text { motivasi dan sosialisasi }\end{array}$ \\
\hline 6 & Lestari & Tidak ada \\
\hline 7 & Tangguh & BLH berupa komposter \\
\hline 8 & RT.40 RW.09 & Kelurahan \\
\hline 9 & Empat Lima & Tidak ada \\
\hline 10 & Berseri & BLH berupa komposter \\
\hline 11 & Rambadia & Tidak ada \\
\hline 12 & Telu Songgo & $\begin{array}{l}\text { BLH, DKP } \\
\text { sosialisasi }\end{array}$ \\
\hline 13 & RT.11 RW.03 & Tidak ada \\
\hline 14 & RT.19 RW.05 & BLH dan DKP \\
\hline 15 & RT.41 RW.09 & $\begin{array}{l}\text { BLH, DKP } \\
\text { sosialisasi }\end{array}$ \\
\hline
\end{tabular}

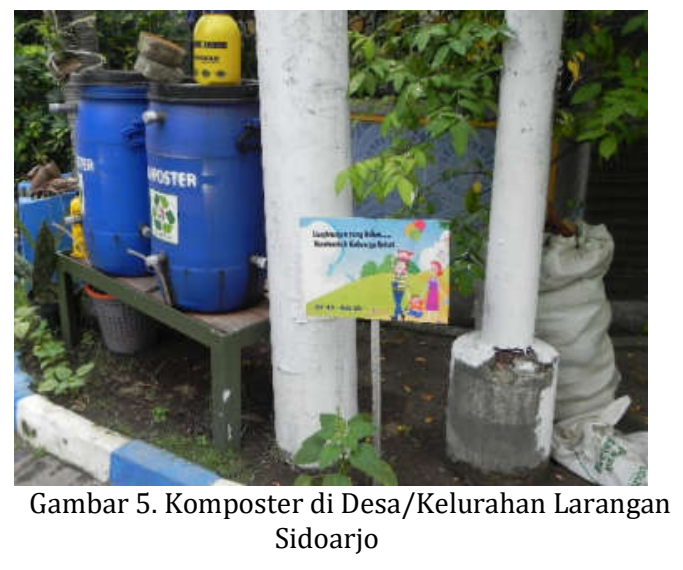

\section{KESIMPULAN}

Berdasarkan hasil identifikasi bank sampah di Kelurahan Larangan Kabupaten Sidoarjo yang telah dijelaskan sebelumnya, bahwa jumlah nasabah aktif menunjukkan kesadaran masyarakan yang baik dalam berpartisipasi pada bank sampah, yaitu jumlah nasabah aktif 
paling tinggi berasal dari bank sampah RT.47 RW.09 dan RT.11 RW.03 dengan jumlah @60 orang. Sedangkan jumlah terendah yaitu 11 orang, berasal dari bank sampah RT.41 RW.09.

Besaran volume sampah yang dikelola tiap bulan rata-rata $(\mathrm{Kg})$ menunjukkan jumlah yang baik dan diharapkan selain mengurangi limbah sampah, sehingga lingkungan menjadi bersih dan sehat. Limbah sampah juga dimanfaatkan untuk meningkatkan pendapatan para nasabah bank sampah khususnya di Kelurahan Larangan Kabupaten Sidoarjo, hal ini dapat dilihat dari omzet setiap bulannya. Untuk nilai omzet terbesar berasal dari bank sampah Saling Asih (Sadar Lingkungan Anggrek Bersih) Kelurahan Larangan sebesar Rp 1.050.000,00. Sedangkan sisanya bervariasi dengan omzet yang diperoleh pada masing-masing bank sampah di desa/keluraha Larangan Sidoarjo..

Sedangkan analisis potensi dan masalah pengelolaan bank sampah mengenai permasalahan yang terjadi baik permasalahan internal lembaga, permasalahan teknis, dan permasalahan di luar lembaga. Permasalahan internal lembaga yang terjadi cukup banyak hal ini dikarenakan kurangnya kesadaran masyarakat berpartisipasi dalam pengelolaan sampah, sedangkan sisanya meliputi permasalahan kurangnya sumber daya manusia (SDM) pengelola sampah pada bank sampah, sarana dan permasalahan teknis lainnya. Meskipun secara teknis operasional bank sampah di Kelurahan Larangan Kabupaten Sidoarjo tidak mengalami masalah yang signifikan pada permasalahan teknis, namun permasalahan internal lembaga terkait kesadaran masyarakat merupakan masalah besar yang berpengaruh pada keberlanjutan bank sampah. Untuk itu solusi non fisik dalam meningkatan kesadaran dan kapasitas SDM pengelola sangat penting untuk segera dialokasikan. Sedangkan permasalahan di luar lembaga yang terjadi di beberapa bank sampah dikarenakan belum adanya komposter, kurangnya peralatan penunjang serta tidak adanya buku tabungan yang digunakan sebagai laporan, hal ini juga harus segera dicari solusinya. Adanya dukungan pemerintah sangat diperlukan dalam keberlanjutan bank sampah khususnya di Kelurahan Larangan Kabupaten Sidoarjo, adapun dukungan pemerintah yang telah dilaksanakan meliputi pemberian komposter, peralatan penunjang, buku tabungan serta sosialisasi pada masyarakat. Dan diharapkan dukungan dari pemerintah ini dapat merata di barikan pada semua bank sampah khususnya di Kelurahan Larangan Kabupaten Sidoarjo, sehingga keberlanjutan bank sampah tetep baik dan dan dapat terus berkembang dengan baik kedepannya.

\section{DAFTAR PUSTAKA}

Dinas Kesehatan Kabupaten Sidoarjo. 2015. Profil Desa/Kelurahan dalam Rangka Pengembangan Desa/Kelurahan Siaga Aktif di Kabupaten Sidoarjo. Sidoarjo

Kementerian Lingkungan Hidup Republik Indonesia . 2012. Profil Bank Sampah Indonesia Tahun 2012. Jakarta

Peraturan Pemerintah Republik Indonesia Nomor 81 Tahun 2012 Tentang Pengelolaan Sampah Rumah Tangga Dan Sampah Sejenis Sampah Rumah Tangga .

Purwanti, WS., Sumartono, dan Haryono, BS. 2015. Perencanaan Bank Sampah dalam Rangka Pemberdayaan Masyarakat di Kecamatan Kepanjen Kabupaten Malang. Jurnal Universitas Tribhwuana Tunggadewi. Malang.

Undang-Undang Republik Indonesia Nomor 18 Tahun 2008 Tentang Pengelolaan Sampah.

Yayasan Unilever Indonesia. 2013. Buku Panduan Sistem Bank Sampah dan 10 Kisah Sukses. Jakarta 